\title{
VAV Family Gene
}

National Cancer Institute

\section{Source}

National Cancer Institute. VAV Family Gene. NCI Thesaurus. Code C20408.

VAV Family Genes (VAV1, VAV2, and VAV3) encode VAV proteins that respond to similar cell surface receptor tyrosine kinases as GEFs for Rho/Rac family GT Pases, which activate pathways leading to actin cytoskeletal rearrangements, transcriptional alterations, cell differentiation, and/or cell proliferation. VAV proteins contain $\mathrm{CH}, \mathrm{DH}, \mathrm{PH}$, $\mathrm{SH} 2, \mathrm{SH} 3$, and zinc-dependent phorbol-ester and DAG binding domains. VAV1 is expressed exclusively in hematopoietic cells, while VAV2 and VAV3 are more broadly expressed. $(\mathrm{NCl})$ 